\title{
Economic Policy
}

The Centre for Economic Policy Research, London, la Maison des Sciences de l'Homme, Paris, and Cambridge University Press, have joined forces to produce this new journal for the analysis of topical issues in economics from a European perspective.

In two issues per year Economic Policy will cover both macro- and microeconomic topics, with emphasis on the international dimension. Articles are specially commissioned and are discussed by a panel of leading economists in Britain, other European countries and elsewhere. Each paper is followed by a summary of comments from members of the panel.

By identifying emerging policy questions at an early stage, Economic Policy aims to produce timely analysis which will influence the policy debate.

Recent issues have included:

Willem BUITER

Government Deficits Reinterpreted

Paul GEROSKI and Alexis JACQUEMIN

Corporate Competitiveness in Europe

Mervyn KING

Capital Tax Reform

Daniel COHEN

Reassessing Third World Debt

Sweder VAN WIJNBERGEN

The North-South Connection

\section{Subscriptions:}

Volume 2, published in April and October: $\$ 16.00$ ( $\$ 30$ ) for institutions; $£ 9.00$ ( $\$ 15$ ) for individuals; single parts $£ 8.50$ ( $\$ 15$ ); Airmail $£ 8.50$ per year extra

Order your copy today, from:

The Journals Subscription Manager, Cambridge University Press, The Edinburgh Building, Shaftesbury Road, Cambridge CB2 2RU, England or

The Journals Subscription Manager, Cambridge University Press, 32 East 57th Street, New York, NY 10022, U.S.A.

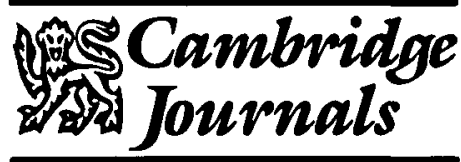




\section{Important Journals from Cambridge}

\section{Economic Policy}

Editors: Georges dé Menil and Richard Portes

Published on behalf of the Centre for

Economic Policy Research and La Maison des Sciences de l'Homme, Economic Policy offers a uniquely independent, non-partisan European forum for analysis of topical issues in economics. Articles are commissioned from leading international economists and policy advisers and are discussed by a panel of eminent economists whose comments in summary follow each paper. The journal discusses the entire range of macro- and microeconomic issues. Two parts per year.

\section{Econometric Theory}

Editor: Peter Phillips

Econometric Theory is an international journal dedicated to advancing theoretical research in econometrics. In addition to articles on original theoretical research, the journal publishes historical studies on the evolution of econometric thought. Each issue contains a 'Problems and Solutions' section and publishes pedagogical papers dealing with educational issues and which discuss new approaches to teaching econometrics. Three parts per year.

\section{Economics and Philosophy}

Editors: Daniel M. Hausman and Michael S. McPherson

Papers in Economics and Philosophy explore the foundations of economics as both a predictive/explanatory enterprise and a normative one. They examine the relevance of economic techniques, methods and conclusions to philosophical questions in ethics and social theory. The journal fosters collaboration between economists and philosophers and bridges the artificial boundaries between them. Two parts a year.

For further information contact:

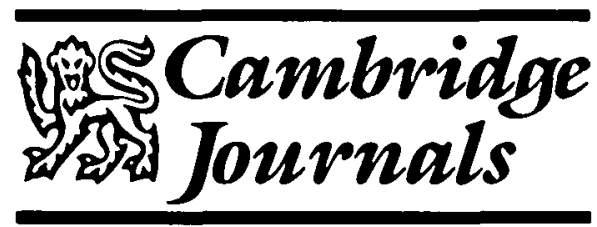

Journal Department

Cambridge University Press

32 East 57 th Street

New York, N.Y. 10022

1-800-221-4512 


\section{ABSTRACTS of Working Papers in ECONOMICS}

The Official Journal of the AWPE Database

Field Key

$i$

Abstracts of Working Papers in Economics

275

Series Index

368

Keyword Index

379

Permuted Title Index

393

Gaining Access to the AWPE Database

414

\section{CAMBRIDGE UNIVERSITY PRESS}

32 East 57th Street, New York, NY 10022

The Pitt Building, Trumpington Street, Cambridge CB2 IRP

10 Stamford Road, Oakleigh, Melbourne 3166, Australia

\section{(C) 1987 Cambridge University Press}

